\title{
Evaluating Product Competitiveness of the Regional Dairy Product Subcomplex (using Kirov region as an example)
}

\author{
Tatiana Baibakova \\ Vyatka State University, \\ Institute of Economics and Management \\ Department of Economics \\ Kirov, Russia \\ baibakova_t_v@mail.ru
}

\author{
Veronica Epinina \\ Volgograd State University, \\ Department of Management \\ Volgograd, Russia \\ econmanag@volsu.ru
}

\author{
Svetlana Korobova \\ Volgograd State University, \\ Department of Management \\ Volgograd, Russia \\ manag@volsu.ru
}

\begin{abstract}
The article considers the main methods used for evaluating the products competitiveness. Among the considered approaches the authors have chosen the methodology that assumes a comprehensive evaluation of the products competitiveness of the regional dairy product subcomplex using an integral index. The authors have proved that the enterprises necessity to strive for financial stability of activities requires constant study of changes in the dairy industry development, theoretical substantiation of the main factors determining the dairy products competitiveness and developing ways and means to increase it on this basis. The considered methodology has been approved on the example of the dairy product subcomplex of Kirov region. It has been found out that the most competitive product is dairy products of the PLC "Kirov Dairy Plant" in terms of relation to the products of the Kirov region enterprises, since these products have the highest integral index of competitiveness. The authors have come to the conclusion that the considered methodology can be used successfully for evaluating the products competitiveness of the dairy product subcomplex of any region.
\end{abstract}

Keywords - competitiveness, region, dairy product subcomplex, products, evaluation, integral index of competitiveness, methodology, Kirov region

\section{INTRODUCTION}

In the modern world competition is the necessary condition for existence and development of any organization. It is competition that makes any manufacturer analyze and study the customers' needs, update his products, improve production technologies, improve the quality of manufactured products and provided services, and improve the system of trade and after-sales services. In turn, the concept of competition is closely related to such economic term as competitiveness.

In fact, in order to maintain and strengthen positions in the market, an enterprise must create products that are suitable for a buyer by consumer properties and cost characteristics. There is no single opinion about the essence of competitiveness, methods of its evaluation and about factors determining the products competitiveness.

Along with the diversity of studied problems of increasing the dairy products competitiveness, a number of aspects, such as indicators and methods used in evaluating and diagnosing the dairy products competitiveness, require further in-depth study.

The purpose of the study is to evaluate the products competitiveness of the region's dairy product subcomplex. Dairy products subcomplex of Kirov region has been chosen as an object of the research. 
The necessary condition for analyzing the competitiveness is considering various approaches to the definition of this term.

\section{MATERIALS AND Methods (MODEL)}

The authors consider the competitiveness as a set of qualitative, economic characteristics and consumer properties that ensure the maximum possible level of consumer preferences satisfaction relative to similar products.

Evaluation and diagnosis of dairy products competitiveness have their own specific features. When choosing a method for evaluating dairy products competitiveness, first of all it is necessary to take into account the specific nature of the products as well as the price-quality ratio, which is the simplest and most specific indicator allowing us to give a definite answer about more preferable types of dairy products to a consumer.

There is a great variety of methodologies for evaluating the competitiveness of products $[1,2,3,4,5,6,7,8,9,10,11,12$, 13], which can be applied in evaluating the dairy products competitiveness. All methodologies are based on different methods. Nowadays, there are five methods of competitiveness evaluation: point, differential, complex, mixed and index methods.

The methodology for evaluating the products competitiveness on the basis of the point method has been proposed by Fatkhutdinov R. A. [12]. He describes the methodology for evaluating the competitiveness according to the system 11111-55555. This methodology determines factors that affect the competitiveness of products, then these factors are evaluated and they are given points from 1 to 5 . And then these points are put together. Under this system, the minimum value of competitiveness will be 5 , and the maximum one will be 25 .

The evaluation is performed by the relevant experts. As a result, certain codes of products competitiveness are obtained. For example, inferior products offered at a very high price and which also have low rates for other compared parameters, will have competitiveness 12112 .

While using the differential method, the indicators comparison of the products competitiveness takes place. These indicators are compared with a benchmark or a comparative base. As a result of it, first of all, the advantage or disadvantage in the competitive struggle with respect to the competitor's products is determined. As a rule, the conclusion about the competitiveness level of products is made on the basis of comparing the obtained value of the indicator with "one". If the indicator is more than "one", then the products satisfy the competitive preferences of consumers, and therefore, it is competitive. Despite the simplicity, this method has some disadvantages. This method can only be used if the evaluation indicators are interrelated. In addition, the significance of each indicator is not taken into account, so it can turn out that a significant indicator has received a minimal rating, and a less significant one has got a high score, and as a result, the conclusion has been made about the sufficient level of products competitiveness.
Under the complex method, one uses complex indicators that consist of individual indicators, that is, this method ensures the interrelation of indicators, as well as their significance. When evaluating the complex indicators obtained, also the comparison with "one" is made. And on the basis of this comparison we can make the conclusion that the analyzed products are inferior (less than "one"), correspond (equal to "one") or exceed the base product - the competitor's products - and exceed "one".

The use of the mixed method for evaluating the products competitiveness is carried out on the basis of combining the first two methods: differential and complex ones.

When using the index method in the process of evaluating the products competitiveness, we calculate the competitiveness index, which consist of three indicators. They are quantitative, qualitative and cost indicators.

The first indicator shows the wide range of products properties, the second indicator determines the depth of the technical component for each property of the product, and the third indicator includes the sales price of products and the cost of their consumption, that is, the input costs and operating costs. If we sum these three indicators up, and as a result, we will obtain the data value "one", this means that this product is in demand among buyers and, therefore, it is competitive.

With regard to dairy products, the index approach allows us, firstly, to record the actual position of products in the market, and secondly, to use the results in developing measures to increase the final indicator, due to the achieved level of the evaluation indicators system.

Filobokova L., Ulanova I. [13] suggest to perform the evaluation of dairy products competitiveness in relation to competitors in the market according to the entire set of parameters, namely: consumer properties, social and economic characteristics. And initially, individual indicators are calculated in the context of consumer properties and social, economic characteristics, and then the group indicators are calculated in the same context. And then on the basis of group indicators one calculates the integral index of products competitiveness. In more detail, the individual and group indicators are presented in table 1 . 
TABLE I. INDICATORS OF EVALUATING THE DAIRY PRODUCTS COMPETITIVENESS [13]

\begin{tabular}{|c|c|c|}
\hline The Indicator Name & Formula & $\begin{array}{c}\text { Definition of } \\
\text { Formula Elements } \\
\end{array}$ \\
\hline \multicolumn{3}{|c|}{ Individual Indicators } \\
\hline $\begin{array}{l}\text { An Individual } \\
\text { competitiveness } \\
\text { indicator (of an } \\
\text { individual type of } \\
\text { products) according } \\
\text { to consumer } \\
\text { properties }\left(\mathrm{IC}_{\mathrm{nn}}\right)\end{array}$ & $I C_{n n}=\frac{\sum_{i=1}^{n} x_{i} \times C_{i}}{n}$ & $\begin{array}{l}\mathrm{x}_{\mathrm{i}}-\text { an element of the } \\
\text { corresponding } \\
\text { characteristic; } \\
\mathrm{c}_{\mathrm{i}}-\text { an element } \\
\text { significance } \\
\text { coefficient; } \\
\mathrm{n}-\mathrm{a} \text { number of } \\
\text { elements of the } \\
\text { corresponding } \\
\text { characteristic; } \\
\mathrm{i}-\text { a parametric index. }\end{array}$ \\
\hline $\begin{array}{l}\text { An individual } \\
\text { products } \\
\text { competitiveness } \\
\text { indicator of milk } \\
\text { processing factories } \\
\text { according to } \\
\text { economic } \\
\text { characteristics (ICE) }\end{array}$ & $I C E=\frac{P_{n}}{P_{r}}$ & $\begin{array}{l}\mathrm{P}_{\mathrm{n}} \text { - profitability of a } \\
\text { particular type of } \\
\text { dairy products of the } \\
\text { producing } \\
\text { organization; } \\
\mathrm{P}_{\mathrm{r}}-\text { the reference } \\
\text { profitability of a } \\
\text { particular type of } \\
\text { dairy products in the } \\
\text { regional market. }\end{array}$ \\
\hline $\begin{array}{l}\text { An individual } \\
\text { competitiveness } \\
\text { indicator of products } \\
\text { according to social } \\
\text { characteristics (CIS) }\end{array}$ & $C I S=\frac{D P_{n}}{D P_{r}}$ & $\begin{array}{l}\mathrm{DP}_{\mathrm{n}}-\text { the share of } \\
\text { consuming a particular } \\
\text { type of products in } \\
\text { total sales of dairy } \\
\text { products; } \\
\mathrm{DP}_{\mathrm{r}} \text { - the reference } \\
\text { share of consuming a } \\
\text { particular type of } \\
\text { products in total sales } \\
\text { of dairy products. }\end{array}$ \\
\hline $\begin{array}{l}\text { An individual } \\
\text { products } \\
\text { competitiveness } \\
\text { indicator of milk } \\
\text { processing factories } \\
\text { according to } \\
\text { ecological } \\
\text { characteristics } \\
\left(\mathrm{ICE}_{\mathrm{k}}\right) \\
\end{array}$ & $I C E_{k}=$ & $\begin{array}{l}\mathrm{C}_{\mathrm{p}}-\text { costs for } \\
\text { ecological and nature } \\
\text { protection measures } \\
\text { per } 1 \text { ton of dairy } \\
\text { products sold; } \\
\mathrm{C}_{\mathrm{e}}-\text { the reference } \\
\text { costs for ecological } \\
\text { and nature protection } \\
\text { measures per } 1 \text { ton of } \\
\text { dairy products sold. }\end{array}$ \\
\hline \multicolumn{3}{|c|}{ Group Indicators } \\
\hline $\begin{array}{l}\text { Group indicator of } \\
\text { competitiveness } \\
\text { according to } \\
\text { consumer properties } \\
\left(\mathrm{CG}_{\mathrm{nn}}\right)\end{array}$ & $C G_{n n}=\sum_{i=1} I C_{n i}$ & $\begin{array}{ll}\mathrm{IC}_{\mathrm{n}}-\mathrm{an} \text { individual } \\
\text { indicator } \\
\text { competitiveness } \\
\text { according } & \\
\text { consumer } & \text { to } \\
\text { properties; } & \\
\mathrm{n}-\mathrm{a} \text { number } & \text { of } \\
\text { analyzed } & \\
\text { characteristics. } & \end{array}$ \\
\hline $\begin{array}{l}\text { A group products } \\
\text { competitiveness } \\
\text { indicator of milk } \\
\text { processing factories }\end{array}$ & $G C E=\frac{\sum_{i=1}^{n} I C E}{n}$ & $\begin{array}{l}\mathrm{n}-\mathrm{a} \text { number of } \\
\text { analyzed subjects. }\end{array}$ \\
\hline $\begin{array}{ll}\text { according } & \text { to } \\
\text { economic } & \\
\text { characteristics } & \\
\text { (GCE) } & \end{array}$ & & \\
\hline $\begin{array}{l}\text { The integral } \\
\text { indicator of products } \\
\text { competitiveness } \\
\left(\mathrm{C}_{n}\right)\end{array}$ & \multicolumn{2}{|c|}{$C_{n}=\sqrt[n-1]{C G_{n n} \times G C E \times C I S \times I C E_{k}}$} \\
\hline
\end{tabular}

Having used the presented methodology, we have performed the products competitiveness evaluation of the dairy product subcomplex in Kirov region.

\section{RESULTS AND DISCUSSION}

The leading producer of dairy products in Kirov region is the private limited company (PLC) "Kirov Dairy Plant". Currently, the plant produces about 40 types of dairy products. Dairy products of this plant are promoted under the trademark "Vyatushka". At the end of 2016 the share of the enterprise in the total volume of processed milk in the market of Kirov region was $51.26 \%$.

The real volume of processed milk in 2014 was 136140 tons, in 2015 it was 140,900 tons, and in 2016 it accounted for 132,762.4 tons. The PLC "Kirov Dairy Plant" annually produces approximately $60 \%$ of liquid processed milk and 63 $\%$ of dairy products from the total volume of dairy products produced in Kirov region. At the same time, the PLC "Kirov Dairy Plant" is the only producer of dried milk in Kirov region. More than $50 \%$ of the whole assortment of dairy products offered in Kirov Region market belongs to the PLC "Kirov Dairy Plant".

With the help of the point method of Filobokova L. and Ulanova I. we have performed the competitiveness evaluation of dairy producers in Kirov region (Table II). During the evaluation, we have identified the leading producers of the region. They are: the Private Limited Company (PLC) "Kirov Dairy Plant", the Joint Stock Company (JSC) "Laktis", the Limited Liability Company (LLC) "Kirov Dairy Company".

TABLE II. THE EVAluation Results OF MiLK PRODUCERS COMPETITIVENESS IN KIROV REGION (IN POINTS)

\begin{tabular}{|l|c|}
\hline \multicolumn{1}{|c|}{ Companies } & $\begin{array}{c}\text { The } \\
\text { Number of } \\
\text { Points }\end{array}$ \\
\hline The PLC "Kirov Dairy Plant" & 146.4 \\
\hline The JSC "Laktis" & 79.32 \\
\hline The LLC "Kirov Dairy Company" & 75.22 \\
\hline The JSC "Vozhgaly Dairy and Cheese Plant" & 47.67 \\
\hline $\begin{array}{l}\text { The LLC Inter Sectoral Research-and-Production } \\
\text { Complex (ISRPC) "Vyatkabioprom" }\end{array}$ & 25.76 \\
\hline The SC "Slobodskoi Dairy Plant" & 21.38 \\
\hline The JSC "Yantar" & 13.28 \\
\hline The LLC "Kotelnich Dairy Plant" & 13.03 \\
\hline The LLC "Bogorodsk Dairy Plant" & 12.38 \\
\hline The JSC "Suna Dairy and Cheese Plant" & 1.59 \\
\hline The PLC "Darovskoi Dairy and Cheese Plant" & 0.99 \\
\hline
\end{tabular}

Further on, we have performed the dairy products competitiveness evaluation of such producers as the PLC "Kirov Dairy Plant", the JSC "Vozhgaly Dairy and Cheese Plant", the LLC "Kirov Dairy Company", the LLC ISRPC "Vyatkabioprom", the JSC "Laktis". The choice of these producers is explained by the fact that they have the maximum number of points obtained in the process of evaluating the competitiveness of dairy producers in Kirov region.

Evaluation of the dairy products competitiveness involves the study of the assortment portfolio of each company. The products assortment of each enterprise in Kirov region has its differences. 
The PLC "Kirov Dairy Plant" produces products on every segment of the market. The assortment saturation is 80 positions, which is its absolute advantage in comparison with other companies. In addition, the PLC "Kirov Dairy Plant" is the only enterprise in Kirov region that produces acidophilus milk and dried fat-free milk. The analysis of the assortment of the LLC "Kirov Dairy Company" has shown that only two assortment groups - whole milk and fat and oil products make up the company's products. Despite a small number of assortment groups, the LLC "Kirov Dairy Company" produces 54 names of various products. The assortment of dairy products of the JSC "Laktis" consists of whole milk (41 positions), fat and oil products (3 positions), and a group of cheeses (6 positions).

The JSC "Vozhgaly Dairy and Cheese Plant" specializes in the production of fat-and-oil products and cheeses. The share of assortment positions of cheeses and cheese products accounts for $39.5 \%$ of all manufactured products. The same direction is supported by the LLC ISRPC "Vyatkabiobrom", in the assortment portfolio of which there are about 45 positions of cheese products nowadays.

On the basis of individual indicators, a group indicator is calculated for consumer properties and economic characteristics (TABLE III, TABLE IV).

TABLE III. THE GROUP INDICATOR OF DAIRY PRODUCTS COMPETITIVENESS FOR CONSUMER PROPERTIES WITH REGARD TO THE SIGNIFICANCE COEFFICIENT

\begin{tabular}{|l|c|c|}
\hline \multicolumn{1}{|c|}{ Companies } & $\begin{array}{c}\text { The Products of } \\
\text { the PLC "Kirov } \\
\text { Dairy Plant" in } \\
\text { Relation to } \\
\text { Competitors }\end{array}$ & $\begin{array}{c}\text { The Products of } \\
\text { Competitors in } \\
\text { Relation to the } \\
\text { PLC "Kirov } \\
\text { Dairy Plant" }\end{array}$ \\
\hline The LLC "Kirov Dairy Company" & 0.9112 & 0.7066 \\
\hline The JSC "Laktis" & 1.027 & 0.6893 \\
\hline $\begin{array}{l}\text { The JSC "Vozhgaly Dairy and } \\
\text { Cheese Plant" } \\
\text { завод» }\end{array}$ & 1.2284 & 0.5595 \\
\hline The LLC ISRPC "Vyatkabioprom" & 1.1028 & 0.5854 \\
\hline
\end{tabular}

The PLC "Kirov Dairy Plant" has a higher consumer property than its competitors. The products of this plant are of high quality and the largest assortment.

TABLE IV. THE GROUP INDICATOR OF DAIRY PRODUCTS COMPETITIVENESS FOR ECONOMIC CHARACTERISTICS WITH REGARD TO THE SIGNIFICANCE COEFFICIENT

\begin{tabular}{|l|c|c|}
\hline \multicolumn{1}{|c|}{ Companies } & $\begin{array}{c}\text { The Products of } \\
\text { the PLC "Kirov } \\
\text { Dairy Plant" in } \\
\text { Relation to } \\
\text { Competitors }\end{array}$ & $\begin{array}{c}\text { The Products of } \\
\text { Competitors in } \\
\text { Relation to the } \\
\text { PLC "Kirov } \\
\text { Dairy Plant" }\end{array}$ \\
\hline The LLC "Kirov Dairy Company" & 0.99 & 1.02 \\
\hline The JSC "Laktis" & 0.99 & 1.01 \\
\hline $\begin{array}{l}\text { The JSC "Vozhgaly Dairy and } \\
\text { Cheese Plant" }\end{array}$ & 1.005 & 0.996 \\
\hline The LLC ISRPC "Vyatkabioprom" & 1.008 & 0.993 \\
\hline
\end{tabular}

To determine the integrated evaluation of the dairy products competitiveness in comparison with the milk processing enterprises in Kirov region, it is necessary to determine the integral index of competitiveness (TABLE V).
TABLE V. THE INTEGRAL INDEX OF DAIRY PRODUCTS COMPETITIVENESS

\begin{tabular}{|l|c|c|}
\hline \multicolumn{1}{|c|}{ Companies } & $\begin{array}{c}\text { The Products of } \\
\text { the PLC "Kirov } \\
\text { Dairy Plant" in } \\
\text { Relation to } \\
\text { Competitors }\end{array}$ & $\begin{array}{c}\text { The Products of } \\
\text { Competitors in } \\
\text { Relation to the } \\
\text { PLC "Kirov } \\
\text { Dairy Plant" }\end{array}$ \\
\hline The LLC "Kirov Dairy Company" & 4.38 & 3.30 \\
\hline The JSC "Laktis" & 4.94 & 3.25 \\
\hline $\begin{array}{l}\text { The JSC "Vozhgaly Dairy and } \\
\text { Cheese Plant" }\end{array}$ & 5.82 & 2.67 \\
\hline The LLC ISRPC "Vyatkabioprom" & 5.21 & 2.81 \\
\hline
\end{tabular}

In May 2016, a high-tech shop for the production of fatfree, agglomerated, high-quality dried milk was launched at the Kirov Dairy Plant. There is no production of such a product on the territory of the Russian Federation, the requirements for it are met by imports (it is used in the production of high quality chocolate, baby food, mayonnaise, artificial butter, etc.).

The production capacity of the plant is up to 4,200 tons of fat-free milk per year, while approximately $95 \%$ of the production is delivered outside the region. At the same time, the PLC "Kirov Dairy Plant" is the only producer of dried milk in Kirov Region.

According to experts, this production will fill up $2 \%$ of the existing dried milk shortage in Russia [14]. It should also be noted that in the period from 2008 to 2012 the PLC "Kirov Dairy Plant" was exporting dried milk to the Baltic countries and the Republic of Poland. Due to the sanctions against the Russian Federation, this type of product is sold in the Russian regions now.

In 2017 the PLC "Kirov Dairy Plant" successfully passed a surveillance audit of the integrated management system (IMS), operating at the enterprise, for the development, production and supply of milk and dairy products for compliance to ISO 9001: 2008 and ISO 22000: 2005.

\section{CONCLUSION}

Thus, from the variety of the methods examined, the authors have selected a methodology that is aimed at evaluating the dairy products competitiveness relative to competitors in the market according to the entire set of consumer properties, social and economic characteristics.

The competitiveness of dairy products is a combination of quality, cost, consumer properties that ensure the maximum degree of dairy products attractiveness for consumers and also allow the organization to have certain competitive advantages over similar products of competitors.

In Kirov region the leader in the assortment of produced dairy products is the PLC "Kirov Dairy Plant", the LLC "Kirov Dairy Company" ranks second, the third company with a wide range of assortment is the JSC "Laktis".

The JSC "Vozhgaly Dairy and Cheese Plant" takes a back seat with comparison to the leader, but the company specializes in the production of cheeses and cheese products. 
The LLC "Bogorodsk Dairy Plant" has a small assortment of produced dairy products, but at present the manufacturer is not aimed at expanding the variety of products, but it is aimed at increasing the quality characteristics of dairy products by improving the raw materials base.

As a result of evaluating the competitiveness of dairy products produced by the enterprises of Kirov region, it is concluded that in terms of competitiveness the first place is occupied by the products of the PLC "Kirov Dairy Plant". The second place is taken by products of the JSC "Vozhgaly Butter and Cheese Plant", and the products of the LLC "Kirov Dairy Company" and the JSC "Lactis" rank third.

Dairy products of the PLC "Kirov Dairy Plant" in relation to products of Kirov region enterprises have the highest integral indicator of competitiveness, and, therefore, they are the most competitive. This competitiveness level was achieved due to high requirements for raw milk for processing, creating conditions for providing its own raw materials base, constant modernization and reconstruction of the production capacity of the manufacturer, the sales system through its own trading net.

The only parameter according to which the products of the PLC "Kirov Dairy Plant" are inferior to the LLC "Kirov Dairy Company" is the quality and design of dairy products packaging. The enterprise needs to work at this parameter in order to strengthen its positions in the market of Kirov region, and compete successfully with other Russian and foreign producers of milk.

The considered methodology can be successfully used for evaluating the products competitiveness of a dairy product subcomplex of any region.

\section{References}

[1] A. Vasilieva, Yu. Kostina, "Evaluation of the assortment competitiveness of of products of the JSC "Dairy Factory Blagoveshchensky"”' in Practical marketing. - 2006. - №8. - pp.1-12.

[2] A. Glukhov, "Evaluation of products competitiveness and the ways to achieve it" in Marketing. - 2009. - №. 2. - pp. 56-64.

[3] M. G. Dolinskaya, I. A. Soloviev, Marketing and competitiveness of industrial products. Moscow: Publishing Standards, 2011. - 125 p.

[4] V. V. Katkov, Management of industrial organization competitiveness: theoretical aspects and practical methods. SPb .: SPbSIEM, 2004. -112 p.

[5] N. Klimova, "Evaluation of food products competitiveness" in AIC: Economics, Management. 2005. - №2. - pp.51-56.

[6] I. M. Lifits, Theory and practice of evaluating goods and services competitiveness. Moscow: Yurayt, 2010. - 223 p.

[7] O. G. Popova, An agrofirm competitiveness and quality of products. Krasnodar: KubanSAU, 2010. - 230 p.

[8] E. I. Semenova, Competitiveness and methods for its evaluation. Moscow: RSACU, 2010. - 27 p.

[9] D. I. Serdobintsev, Increase in milk and dairy products competitiveness on the regional market: the dissertation for the scientific degree of a candidate of economic sciences: 08.00.05. Saratov, 2006. -148 p.

[10] N. A. Trigub, "Methodological problems of evaluating products competitiveness on the example of processing enterprises of the agroindustrial complex" in Problems of forecasting and state regulation of social and economic development: materials of XIII Intern. Scientific Conference, Minsk, October 25-26, 2012: Volume 2. - Minsk: SREI of the Ministry of Economy of the Republic of Belarus, 2012. - pp. 157159.

[11] V. K. Faltsman, "Evaluation of Russian products competitiveness in the world, in the UIC markets, EurAsEC and foreign countries" in Problems of forecasting. - 2014. - №. 1. pp. 87-98.

[12] R. A. Fatkhutdinov, "Innovative management as the system of increasing competitiveness" in Management of the staff. - 2010. - No. 1. - pp. 23-38.

[13] L. Filobokova, I. Ulanova, "Competitiveness evaluation of organizations in dairy-processing industries" in AIC: economy, management. - 2015. - No. 6. - pp.46-51.

[14] The new shop for the production of dried milk in Kirov will reduce the need for its import. [Electronic resource]: Available at: URL: https://milkprice.ru/news/1159-novyi-ceh-po-vypusku-suhogo-molokav-kirove-snizit-potrebnost-ego-importa (Accessed 01 February 2018). 